\title{
Del bautismo de Leguizamón al escritor como un shofar: apuestas integradoras en Gerchunoff
}

Recibido: junio/2019 Aprobado: febrero/2020

\begin{abstract}
Resumen
Este trabajo aborda los libros de Alberto Gerchunoff Los gauchos judios (1910) y El hombre importante (1934) con el fin principal de examinar en sus prólogos, así como en los vínculos entre estos y los textos prologados, las concepciones que allí se presentan sobre los procesos de integración de los inmigrantes judíos a la Argentina y la construcción de la imagen de escritor de Gerchunoff. Como se demostrará, mientras que en Los gauchos judios prima una concepción de la integración coherente con el modelo del crisol de razas, en El hombre importante se defiende el proyecto de una nación pluricultural, y tal transformación se verá reflejada, a su vez, en el modo de elaboración de su imagen de escritor como autor nacional. Asimismo, el estudio de estas obras permitirá una reflexión sobre la función y los rasgos del prólogo en tanto espacio liminar entre el texto prologado y su contexto sociocultural de producción.
\end{abstract}

PALABRAS CLAVE: Alberto Gerchunoff, Los gauchos judíos, El hombre importante, Nación, Judíos

From the Baptism by Leguizamón to the Writer as a Shofar: Integration Processes in Gerchunoff

\begin{abstract}
This paper focuses on The Jewish Gauchos (1910) and The Important Man (1934) by Alberto Gerchunoff with the purpose of analyzing in their prologues, as well as in the links between these and the main texts, the conceptions about the integration processes of the Jewish immigrants to Argentina and the construction of Gerchunoff's author figure. Firstly, I will demonstrate that while a conception of integration consistent with melting pot model prevails in The Jewish Gauchos, The Important Man defends the project of a pluricultural nation. Secondly, I will show
\end{abstract}


that such transformation impacts, in turn, on the way of elaborating Gerchunoff' self-representations as a national author. Finally, the study of these works will allow a reflection on the function of the prologue as a liminal space between the main text and its sociocultural context.

KEYWORDS: Alberto Gerchunoff, The Jewish Gauchos, The Important Man, Nation, Jews

\section{Do batismo de Leguizamón ao escritor como um shofar: apostas integrativas em Gerchunoff}

\section{Resumo}

Este trabalho analisa os livros Os gaúchos judeus (1910) e Ohomem importante (1934), de Alberto Gerchunoff, com o objetivo principal de examinar em seus prólogos, assim como nos vínculos entre eles e os textos centrais, as concepções que aí se apresentam sobre os processos de integração de judeus imigrantes na Argentina e a construção da imagem de Gerchunoff como escritor. Como será demonstrado, enquanto em Os gaúchos judeus prevalece uma concepção de integração coerente com o modelo do melting pot, em Ohomem importante defende-se o projeto de uma nação multicultural, e tal transformação se refletirá, por sua vez, no modo de elaboração de sua imagem de escritor como autor nacional. Da mesma forma, o estudo dessas obras permitirá uma reflexão sobre a função e as características do prólogo como espaço liminar entre o texto do prólogo e seu contexto sociocultural de produção.

PALAVRAS-CHAVE: Alberto Gerchunoff, Os gaúchos judeus, O homem importante, Nação, Judeus

\section{Introducción}

En 1910 la obra Los gauchos judios de Alberto Gerchunoff (1883/1884-1950) es entregada por el autor como una ofrenda de gratitud a su patria de adopción en el cumplimiento del Primer Centenario de la Independencia de la Argentina. Gerchunoff había venido de Rusia hacia 1890 y, tras una infancia en las colonias entrerrianas fundadas por la Jewish Colonization Association, comenzaba entonces a hacerse de un nombre en la bohemia porteña y en los medios periodísticos y literarios de la capital. De hecho, la firma del prologuista de su obra prima, nada menos que Martiniano Leguizamón, importaba una consagración y una bienvenida entre los escritores nacionales. Su prólogo no solo celebra al escritor nacido en Proskuroff como un autor nacional, sino que además propone una lectura del libro según la cual este proclamaría la asimilación idealizada y gozosa de los inmigrantes judíos a la Argentina.

Veinticuatro años después, con una reconocida trayectoria, que incluía su paso por La Nación y diario El Mundo, así como un conjunto significativo de ensayos y textos narrativos (cf. Jaroslavsky de Lowy, 1957; Marquis Stambler, 1985; Feierstein, 2013; Szurmuk, 2018), Gerchunoff da a conocer El hombre importante (1934). Lejos del tono celebratorio y agradecido de la obra de 1910, se lanza allí una sátira que cubre un amplio espectro del campo político-social y que es antecedida por un prólogo, a cargo de un alter ego del autor, en el que, a través de una crítica a las academias y los nacionalismos, emerge una autofiguración autoral renovada y una nueva apuesta sobre los procesos de integración de los inmigrantes judíos al país. 
Este trabajo se propone, en primer lugar, examinar en sendos prólogos de Los gauchos judios y El hombre importante, así como en los vínculos entre estas instancias prefaciales y los textos prologados, la concepción que allí se presenta sobre los procesos de integración de los inmigrantes judíos a la Argentina y la construcción, a través de diversas operaciones discursivas, de la imagen de escritor de Gerchunoff. ${ }^{1}$ Como se verá, en estos prólogos la concepción de la relación entre los inmigrantes y la Argentina, por un lado, y la imagen de escritor, por otro lado, se encuentran interrelacionadas y poseen una dimensión proyectiva que las convierte en verdaderas apuestas de integración de Gerchunoff mismo en tanto autor a la literatura nacional y de su comunidad de origen al nuevo país de residencia.

En segundo lugar, el estudio particular de estas obras de Gerchunoff permitirá una reflexión sobre la función y los rasgos del prólogo en tanto espacio liminar entre, por una parte, la coyuntura histórica y el sistema cultural de producción de la obra y, por otra parte, el texto prologado. Para ello, servirán como un acercamiento teóricoconceptual general que ilumine esta reflexión los trabajos de Gérard Genette (2001) sobre las instancias prefaciales. El autor denomina prefacio o instancia prefacial a toda especie de texto liminar -autoral o alógrafo- que constituya un discurso a propósito del texto que sigue o precede y, recuperando la diferencia derridiana entre prefacio e introducción, le asigna una "historicidad más empírica" que a esta última (Genette, 2001: 137).

\section{El crisol de amor y la unción de Leguizamón}

La coyuntura intelectual del Primer Centenario de Mayo se encuentra atravesada por el florecimiento del nacionalismo cultural. Suscribirían a él autores tan diversos como Manuel Gálvez, Leopoldo Lugones y Ricardo Rojas, quienes, como Alberto Gerchunoff, rindieron entonces también sus honores literarios a la Patria. Eran denominadores comunes de este pensamiento nacionalista el hispanismo lingüístico, el telurismo, el criollismo y el ideario del crisol de razas (Altamirano y Sarlo, 1983). Pero la ambivalencia signó la visión sobre los inmigrantes: celebrados a veces por su fuerza de trabajo, vilipendiados a veces por descaracterizar el "alma de la nación". Así, frente a ellos, la figura del gaucho se recuperaba simbólicamente como arquetipo nacional (Lugones, 1916).

Ante esta coyuntura se comprende que en Los gauchos judios haya una búsqueda de legitimación de la pertenencia a la Nación tanto de los inmigrantes judíos mediante su consustanciación con un determinado imaginario del tipo criollo como de Gerchunoff mismo en tanto autor argentino. Los paratextos de la obra anticipan este mensaje de integración. Por un lado, su título -entre la descripción y el alegato- combina dos universos culturales cuya coherencia aproblemática no era un apriorismo. La índole de esta conjunción se esclarece con la lectura de estas estilizadas estampas de las colonias entrerrianas: esos judíos irían convirtiéndose en gauchos trabajadores a tono con el ideario liberal (cf. De Giovanni, 2000). De este modo, el libro toma el relevo de la transformación en la representación del "jinete de las pampas" que se vislumbra en la obra central de su prologuista, Calandria de Leguizamón, así como en La vuelta de Martín Fierro de José Hernández, en cuyos desenlaces se proclama la necesidad de la conversión del gaucho matrero en peón rural reconciliado con el Estado.

1 Se sigue aquí la concepción de Gramuglio $(1993,2013)$ acerca de la construcción de la imagen de autor, según la cual, "la imagen de escritor refiere a las figuras textuales y a las estrategias, discursivas y a veces no discursivas, que condensan el imaginario de un escritor acerca de la colocación de sí mismo o de su práctica en los espacios literario y social" (2013: 96). 
Por otro lado, la firma del autor y el prologuista manifiestan nuevos vínculos en el campo literario: la obra del autor judeoargentino es introducida por el consagrado escritor del regionalismo entrerriano. Introducción doble: de los lectores a la temática del libro; de este -y su autor- a la literatura nacional. En efecto, el prólogo original de Los gauchos judios es una instancia de construcción de la imagen de escritor delegada por Gerchunoff en un autor reconocido que pudiera abrirle las puertas de la literatura argentina. Es justo mencionar que si este preámbulo textual de Leguizamón fue un salvoconducto, las estampas de Gerchunoff lograrán finalmente sostenerse en el tiempo por sí mismas y por sus múltiples relecturas.

Dicho esto, es indudable que este prefacio alógrafo contribuyó a la consagración del novel autor a través de la inscripción de la escritura gerchunoffiana en una tradición literaria nacional de reciente formación y de una lectura particular de su ideología integracionista. Efectivamente, Leguizamón vincula Los gauchos judíos a la literatura regionalista de Entre Ríos. Así, a tono con el auge del telurismo esencialista, celebra la obra por brindar en sus páginas "sabor argentino" y "paisajes y aromas de una región" (1910: IX). Y juzga, con palabras que se tornan un bautismo literario, que al pintar "una página muy hermosa de la vida provinciana", su autor, al contrario de los jóvenes nativos extraviados en exotismos, "se incorpora al raleado grupo de los escritores nacionales" (1910: XIII). No casualmente en un libro dedicado a las colonias judías, Leguizamón insiste en destacar que lo mejor en él es la descripción de la naturaleza, a la vez que encuentra allí el punto a expandir (1910: XIV). Si algún aspecto de su escritura podía dar a Gerchunoff la "unción" del maestro era la veneración del paisaje entrerriano.

Respecto a la temática del libro, ella es sintetizada por el prologuista como la transformación de los judíos en gauchos y argentinos. Lo significativo es que concibe dicho proceso en la obra y en su contexto histórico como una borradura unilateral y aproblemática de particularidades étnicas, en el cual las mujeres judías tendrían un rol central. Estas "bíblicas campesinas" serían las propiciadoras del pasaje étnicocultural gracias a su belleza:

Ellas representan además un papel importante en el libro, porque son el crisol de amor que está modelando el tipo nuevo, varonil y hermoso del gaucho judío. En vano los viejos rabinos seguirán mesándose las largas barbas al repetir en sus oraciones las lamentaciones seculares de la raza; sus hijos ya entran con desgano a la sinagoga, abandonan los hábitos tradicionales adoptando los trajes y usos de la comarca y adquieren como por lenta infiltración del medio ambiente, con los instintos de libertad, esa independencia brava e inextinguible que timbra con rasgos acentuados el perfil moral de nuestro paisano. (Leguizamón, 1910: XIV)

La lectura de Leguizamón ha sido durante décadas la interpretación canónica de la obra, aun cuando su ideología fuera criticada por su impronta asimilacionista, con diferente tenor crítico, por intelectuales tales como Viñas (1964), Sosnowski (1978) y Senkman (1983). En los últimos años ha habido reinterpretaciones de Los gauchos judios que objetan que haya allí tal tendencia aculturadora, subrayando en el libro elementos del acervo cultural judío y escenas de tensión entre los inmigrantes y el nuevo medio sociocultural (cf.: Lindstrom, 1989; Aizenberg, 2002). Sin embargo, a pesar de ello, es innegable que existe una coincidencia entre sendos textos de prologuista y prologado en cuanto a, por una parte, enfatizar el acrisolamiento y la convivencia interétnica antes que dar cuenta de las fricciones del contacto cultural y, por otra parte, buscar demostrar la consustanciación del autor con la "argentinidad". 
Así, existieron históricamente tensiones vinculadas tanto al contacto interétnico como a la condición de inmigrante de Gerchunoff que no son asumidas en el prólogo y, ${ }^{2}$ en verdad, apenas son tratadas en la obra prologada. En este sentido, José D. Chein señaló cómo el carácter extranjero del autor y su defensa del crisol de razas implicaban una contradicción con algunos supuestos del regionalismo-nacional entrerriano en el que su obra, según su prólogo manifiesta, busca inscribirse. En efecto, frente a la autoctonía provincial de escritores como Leguizamón y Fray Mocho (José S. Álvarez), cuyo nativismo se exalta como credencial de una escritura nacional en los circuitos porteños, y la afirmación tácita en sus obras de la autenticidad del "espíritu de la tierra" como opuesto a sus tergiversaciones por el aluvión inmigratorio (cf. Chein, 2012), el extranjero Gerchunoff se reapropia del telurismo -mediante imágenes que muestran la consustanciación de narrador y personajes con la "nueva tierra de promisión"- para constituirse a sí mismo como escritor provincial y nacional, y para conformar la imagen del "gaucho judío" como campesino honesto y trabajador en armonía con el medio natural y los pobladores del terruño. Prologuista y prologado omiten sistemáticamente estas tensiones.

Respecto a los vínculos interétnicos, es cierto que aparecen en la obra conflictos silenciados en el prefacio - tales como la resistencia de las viejas judías a los matrimonios mixtos o el asesinato de Rabí Abraham por un gaucho-. Pero no solo son ellos, al igual que las inclemencias de plagas y tormentas, constituidos como irrupciones singulares y/o extemporáneas al ambiente de conciliación, sino que se operan una serie de homologaciones entre la cultura de emigración y la cultura del nuevo país que lleva a la borradura de sus diferencias. Así, las campesinas judías tienen ojos de Virgen (Gerchunoff, 1910: 14), Argentina es una nueva Sion (Gerchunoff, 1910: 5) y los gauchos legendarios son semejantes a los patriarcas hebreos (Gerchunoff, 1910: 65). Entre estas homologaciones la principal es la que se produce en un texto sin título, datado en "mayo del Centenario Argentino", y que funciona como un brevísimo prólogo de autor. En esta segunda instancia prologal, se convoca a los judíos a una "conversión cívica" yuxtaponiendo la milenaria celebración pascual de la salida de Egipto con las fiestas de la libertad argentina, la cual habría hecho posible un nuevo Pésaj para el "pueblo errante": la liberación de la Rusia zarista (Gerchunoff, 1910:1).

Pero por sobre todo hay algo que en la obra se correspondía con la exaltación del crisol de razas que realizaba sin tapujos Leguizamón y con la incorporación de Gerchunoff al linaje de los escritores nacionales: el hispanismo de su estructura lingüística. En efecto, a pesar de algunos términos en ídish y hebreo en el texto, o de algunos giros camperos, se privilegia en el discurso del narrador la utilización de un español con inflexiones castizas, a tono con el nacionalismo lingüístico hispanista reinante en el marco del Primer Centenario, llegando incluso a ostentar un estilo cervantino. En ese sentido las suturas lingüísticas del español del narrador sobre el multilingüismo de la colonia se corresponden con la propensión a invisibilizar las tensiones en el encuentro intercultural. ${ }^{3}$

Ahora bien, Leguizamón no solo exalta el "crisol de amor" en las páginas del libro, sino que también considera que el mismo autor es un paradigma de este modelo de integración acrisolado: él se habría argentinizado en el contacto con el suelo de la región y sus habitantes gauchos. De esa misma forma se autorrepresentará Gerchunoff, en cuyos alter egos (el narrador y el peón Jacobo) los marcadores étnicos judíos son

2 Sobre las tensiones entre judíos y no judíos en la Argentina, véase Mirelman (1988) y Freidenberg (2013).

3 A diferencia de la postura de Aizenberg (2002), quien juzga de "idishista" el texto de 1910 de Los gauchos judíos, se considera en este trabajo que a pesar de la presencia de palabras transliteradas desde el ídish y referencias a novelas y al folklore en este idioma, la obra de Gerchunoff se orienta ante todo a una exaltación del español como medio y símbolo de la pertenencia de los inmigrantes a la Argentina, antes que a una reivindicación de la lengua étnica (Di Miro, 2017). 
circunscriptos al pasado. Pero además, Leguizamón exige un mayor acrisolamiento asimilador de su literatura. De este modo, le pide a Gerchunoff, junto a un mayor desarrollo de las descripciones de la naturaleza regional, que deje a un lado "las preocupaciones de la raza" (1910: XV), es decir, el interés por el judaísmo y la vida judía.

Pensando en su autobiografía póstuma, escrita en 1914, donde Gerchunoff afirma que "borró sus orígenes" (Gerchunoff, 2015: 14), podría juzgarse que la lección del prologuista caló hondo en él. Sin embargo, en sus cuentos posteriores no solo el ámbito urbano iría ganando cada vez más terreno -cfr. Cuentos de ayer (1919) y La asamblea de la buhardilla (1925)-, sino que además "lo judío", y su relación con "lo argentino", persistiría en sus preocupaciones de escritor. Así lo testimonia veinticuatro años después de su obra prima el prólogo de El hombre importante... escrito ahora por él mismo.

\section{Una "advertencia pertinente"}

En El hombre importante se narra la biografía de Don Vespasiano Pardeche, un caudillo político encaramado al poder mediante estrategias clientelares, personalismo y el ocultamiento de su ignorancia en un místico silencio. No era difícil ver entonces allí una sátira de la figura de Hipólito Yrigoyen, presidente democrático perteneciente al Partido Radical derrocado el 6 de septiembre de 1930 por un golpe militar de signo conservador. Más aun considerando que el antiyrigoyenismo de Gerchunoff, afiliado al Partido Democrático Progresista desde 1915, había sido ya expresado en escritos suyos aparecidos en las publicaciones La Nota y La Mañana, así como en su libro El nuevo régimen (1918). ${ }^{4}$

En el contexto de producción local y mundial de esta nueva obra de Gerchunoff, la convicción en las virtudes del liberalismo para construir la Nación ya no era un consenso (cf. Halperin Donghi, 2013; Zanata, 1996). El general José Félix Uriburu, que tras el golpe asumió la presidencia hasta su reemplazo por el general Agustín Justo en 1932, sostenía una ideología de tendencia corporativista-nacionalista que se expresaría en diferentes aspectos de su gobierno. ${ }^{5}$ En este sentido, era evidente la afinidad de ideas con grupos y revistas de carácter nacionalista y antidemocrático, tales como La Legión Cívica, La Nueva República, Criterio y La Fronda, entre otros, los cuales no carecían de un componente antisemita en la construcción discursiva de los enemigos del país (Lvovich, 2003; Tato, 2007). Asimismo, el ideal de una nación homogénea étnicamente, perteneciente a la latinidad y librada del "peligro rojo", junto a la crisis económica de 1929, llevaría a poner limitaciones a la política inmigratoria a través de diversos decretos que dejarían poco margen para el ingreso al país de la creciente ola de refugiados judíos, víctimas de la Alemania nazi (Avni, 1983).

Fue también manifestación de esta corriente corporativa-nacionalista la creación en 1931 de la Academia Argentina de Letras (AAL) por un decreto-ley del Poder Ejecutivo Nacional (Glozman, 2013: 462). Dos de sus objetivos centrales, reveladores de la intención de disciplinamiento sobre la lengua y la producción cultural, eran "velar por la corrección y pureza del idioma" y reglamentar los premios literarios nacionales. Por lo demás, dentro del grupo inicial de la AAL -designado por el Presidente- hubo una hegemonía de escritores e intelectuales de un acendrado nacionalismo católico, tales como monseñor Gustavo Franceschi, Manuel Gálvez y Gustavo Martínez de Zuviría (Glozman, 2013: 469). Pero aunque la AAL carecía de lazo formal con la Real Academia

4 Sobre la relación de Gerchunoff con el Partido Democrático Progresista y su visión del radicalismo, véase Laura (1956: 134) y Tato (2006).

5 Tal sustitución se motivó en el rechazo de las elites tradicionales al proyecto corporativista. La frustración de grupos nacionalistas y católicos ante este cambio llevaría a su radicalización (Lvovich, 2003: 295). 
Española y pretendía incorporar a la lengua ciertas "particularidades nacionales", la variedad peninsular siguió siendo su norma de ejemplaridad idiomática (Blanco, 1995). Gerchunoff rechazó entonces la invitación a ser uno de sus miembros alegando la incompatibilidad de la libertad creadora de todo escritor con las instituciones académicas (cf. "Presentó su renuncia", 1931).

En el prólogo de El hombre importante desarrollaría aún más los argumentos de su negativa, haciéndose transparente que en la decisión estaba implicada la relación del nacimiento de la Academia con la ideología nacionalista. Efectivamente, ecos y marcas de ese clima político-social y de los avatares del campo literario-intelectual dejaron sus huellas en la "Advertencia pertinente", la cual se asigna a sí misma una función prologal en esta novela. Se trata de un prólogo elaborado a partir de la ficcionalización de una respuesta epistolar de "el autor de El hombre importante" al "Secretario perpetuo de La Academia de Letras y de Historia de Caracatambo", a quien le urge saber por qué aquel rehusó ser miembro de dicha academia y si la historia de Pardeche es o no una biografía verídica (Gerchunoff, 1960: 11). ${ }^{6}$

El extenso prólogo de cuarenta y nueve páginas se dedica casi en su totalidad a responder indirectamente a la primera de estas cuestiones -en la que resuena el rechazo de Gerchunoff a la AAL- a través de un "ensayo sobre las academias" (Gerchunoff, 1960: 44), que lo es, en verdad, sobre lo que va perfilándose tácitamente, a través de imágenes, ejemplos y descripciones de sus múltiples manifestaciones, como "el espíritu académico". Se trata de un "espíritu" homogeneizador, normativo y excluyente que esteriliza toda potencialidad creativa y elimina las diferencias étnicas, culturales, de clase y subjetivas que no se ajustan a la norma. En la "Advertencia pertinente" este espíritu académico se muestra como el impulso constitutivo no solo de las academias, sino también de los gobiernos y las sociedades antidemocráticas.

De allí que el rechazo a la "Academia de Caracatambo" se ligue implícitamente a su vínculo con un gobierno autoritario. Su fundador es el "difunto y benemérito general Sofanor Bermúdez", un tiránico caudillo de la imaginaria república latinoamericana de Caracatambo a quien no sería difícil asociar con el general Uriburu. Pero sobre todo dicho rechazo se debe al carácter intrínsecamente arbitrario y retrógrado de este tipo de instituciones, y a su correspondencia-según el texto- con la impronta de todo régimen conservador. Como la Academia Francesa o la Real Academia Española, cuyo desarrollo se expone como ejemplo, ellas pierden el contacto con la "actividad viva y cambiante del genio popular" sobre el idioma y la literatura. Por este motivo, la presencia allí de los escritores, "cajas de resonancia de ese genio multiforme" (Gerchunoff, 1960: 17), se juzga como una sinrazón.

El prologuista observa entonces la presencia del espíritu académico no solo constitutivamente en el ámbito de academias culturales y científicas, sino también en la organización social y política de las naciones en periodos de creciente autoritarismo y segregación, que no casualmente coinciden con la exaltación de estas instituciones. En este sentido, es presentado como caso paradigmático, aún más que la Italia de Mussolini-quien "hizo la comedia de la academia" (Gerchunoff, 1960: 41)-, la situación en Alemania desde fines del siglo XIX. Se afirma así que Guillermo de Hohenzollern "academizó al espíritu alemán, lo aprusianó y wilhelmizó hasta acordarlo al ritmo de su respiración. [...]. Academizó a los sesenta y seis millones de alemanes y se propuso fundar una academia" (Gerchunoff, 1960:33-34)... Aunque no lo habría hecho porque, de fundarla, la mayoría de sus miembros hubieran tenido que ser inevitablemente

6 Se extiende aquí la denominación de "prólogo ficcional”, utilizada por Genette para los prefacios atribuidos a un enunciador inexistente (2001: 154), a casos como la "Advertencia pertinente" donde ellos se dirigen explícitamente a un destinatario irreal. 
judíos. El antisemitismo de Hitler es considerado entonces como una continuación de este proceso academizador que se afana en hacer de Alemania una "compacta tribu aria". De allí que se lance la ironía de que con la persecución de judíos y personas de espíritu honorable Hitler podrá realizar el propósito de su antecesor: "Ya no hay en Alemania ni sabios ni escritores, ni poetas, ni artistas. Puede hacer una academia..." (Gerchunoff, 1960: 36). Avance del nacionalismo y del academicismo quedan puestos así en paralelo en la "Advertencia pertinente".

Los rasgos del espíritu académico que los anima, rígido, estéril, totalitario e inflexiblemente tradicionalista, son condensados en la figura de la "comunidad de Orígenes". Según se explica, Orígenes tenía "el defecto de la excesiva perfección, que es un defecto en la vida y en el arte" (Gerchunoff, 1960: 28), y esa obsesión por la pureza inmaculada lo condujo al acto inhumano de la castración. De allí que quienes se afanen en la entronización de una normatividad excluyente, de una "perfección suma y destilada indefectibilidad" (Gerchunoff, 1960: 29), sean considerados miembros virtuales de esa comunidad monolítica impugnada por el prologuista. De allí también que se interpele a Azorín, a Pío Baroja y a Marañón, pertenecientes a la Academia, a no frecuentar la "amistad de Orígenes" en pleno auge de la Confederación Española de Derechas Autónomas (CEDA).

Es en este rechazo al carácter homogeneizador del espíritu académico donde puede leerse un posicionamiento del prologuista -alter ego de Gerchunoff- en cuanto a los procesos de integración de inmigrantes, y particularmente de inmigrantes judíos, a la Argentina. Contra la normatividad de las academias, que pretende exorcizar las "contaminaciones" de la lengua y la cultura, contra la "comunidad de Orígenes", que cercena una parte de su cuerpo -vuelto alegoría del cuerpo comunitario y nacionalpara mantener una pureza estéril, se eleva en el prólogo, como celebración al espíritu antiacadémico, un canto al aluvión inmigratorio hacia a la Argentina que recuerda aquel otro entonado por Rubén Darío en su "Canto a la Argentina" en 1910.

El Río de la Plata riza con la racha que hincha las velas de los pesados veleros y las piezas de ropa tendidas en los cables de las motonaves, que descargaron ayer su carga de inmigrantes, con gringos iguales al padre de Carlos Pellegrini y al padre del poeta de este libro, el Río de la Plata, riza su bullidora inmensidad. [...]. Las grúas también se han vuelto locas; se emborracharon con las profecías de D. Domingo Faustino Sarmiento y esparcen sobre los pueblos océanos de trigo y maíz y cordilleras de cuartos de novillo "chilled", para que los pueblos digan ¡Salud, Argentina!, como yo digo, en representación de los argentinos, ¡mundo, salud! El mundo es antiacadémico, es caótico, bailador y cantador como el rey David, y mañana tras mañana está de parto y pare el mundo. (Gerchunoff, 1960: 31-32, subrayado propio)

Una vez más vuelve a celebrarse la unión de los hombres del mundo y la Argentina, pero ahora no se encuentran ya indicios de la ideología de la fusión acrisolada de todas las particularidades étnicas. Por el contrario, cuando el autor, haciendo referencia a la situación en la Alemania nazi, brinda una definición general de los judíos, subraya su carácter no asimilable: "Los judíos excluidos como colectividad, perseguidos como raza y como credo, porque son una persistencia de Cristo y una diferenciación, o sea un fermento de originalidad, de levadura no fusible, descoinciden con la impermeabilidad de lo estratificable" (Gerchunoff, 1960:35). Así, un rasgo prototípico atribuido tradicionalmente a los judíos en el discurso judeofóbico, su carácter inasimilable, es vuelto por Gerchunoff un valor ponderable ante el avance del espíritu academizador.

De esta forma, un nuevo modo de pensar la integración va entramándose en las imágenes y declaraciones de esta instancia prologal. Frente al crisol de razas parecen ahora exaltarse las virtudes de la conservación del pluralismo étnico-cultural dentro de la 
comunidad nacional. Sin embargo, aunque ya no se vislumbra como meta deseable el progresivo abandono de las culturas de emigración, reaparecen nuevamente en el discurso figuras de pasaje y operaciones de homologación que subrayan la identificación con lo "argentino". Entre las primeras, sobresale aquella que expresa la transformación del hijo de inmigrantes en representante de los argentinos, mediante una construcción retórica que, desplazando la extranjería al padre, retacea aun pudorosamente el verdadero origen ruso. En cuanto a las operaciones de homologación, estas trazan una continuidad entre el judaísmo y el cristianismo a través de frases como "los judíos son una persistencia de Cristo" que señalan el afán de hallar la unidad en la pluralidad. Incluso el mismo espíritu antiacadémico es equiparado no solo al alma del Rey David, sino también al Espíritu Santo, definido aquí como "llama de la creación", que con las tijeras de su pico de paloma raja los reglamentos de las instituciones y se expresa a través de los auténticos artistas, filósofos y creadores de esquemas sociales (Gerchunoff, 1960: 18).

En efecto, frente a las academias y su espíritu, se proclama como labor esencial de los escritores defender la libertad creativa del Espíritu Santo, en el ámbito cultural y social, entendida como condición sine qua non para "parir" nuevas comunidades fraternales. El mismo prologuista se construye a través de su discurso como encarnación ejemplar de aquello que tácitamente es postulado como el auténtico deberser de todo escritor. Y ello no únicamente por lo dicho, es decir, su crítica a las múltiples manifestaciones de las tendencias totalitarias, sino también por las marcas discursivas que manifiestan una unión creativa entre elementos de la cultura judía y la cultura occidental. Ejemplos de ello son metáforas como "Sanhedrín lingüístico" para referirse a la Academia.

Es justamente por asumir plenamente su responsabilidad como autor que este prologuista-narrador afirma haber renunciado a las Academias. Y esta afirmación se concretiza simbólicamente a través de una imagen del escritor en que la conjunción entre la tradición judía y la tradición cristiana se vuelve paradigma de la defensa en pos de la fraternidad humana en que ellos deben implicarse:

\footnotetext{
Este procedimiento del Espíritu Santo encierra una grave lección en estos tiempos de mutaciones súbitas, de tradicionalismos y de revolucionarismos, de Stalin, el bárbaro grande que odia al pensador no comunista; de Hitler, el bárbaro de cara de perro, de ladrido de perro, de payaso sin tristeza de payaso, que odia a los que encarnan con su verbo indómito el inabatible decoro de la humanidad. Por estos motivos, porque el escritor es el shofar, el cuerno de macho cabrío en que suena y canta el Espíritu Santo, rehusé el honor de figurar en la lista de los miembros correspondientes de la Academia de Caracatambo. Es que antes había renunciado, en mi propio país, a idéntica distinción. (Gerchunoff, 1960: 19, subrayado propio)
}

El shofar es un instrumento ritual del judaísmo mencionado por primera vez en Éxodo 19:16, en la teofanía del Sinaí, como el cuerno que anunciaría el Año del Jubileo, y luego en Levítico 25-9: 10, como instrumento para señalar la proclamación de "la libertad en toda la tierra" (Lewis, 2007: 506). Pero aquí es el Espíritu Santo cristiano quien vibra en él, cifrándose de este modo un mensaje de unión y tolerancia en esta metáfora sobre el escritor. Este mensaje se cimenta, en primera instancia, en el sincretismo de dos tradiciones diversas que para Gerchunoff coinciden en su dimensión mesiánica. Shofary Espíritu Santo anuncian, como debe hacerlo todo escritor, "la venida cotidiana del Mesías", y la razón última de este mesianismo es la libertad y la paz entre los hombres. ${ }^{7}$ Pero también, en segunda instancia, en la utilización de un hebraísmo 
para definir nada menos que la misión de los hombres de Letras en un contexto en que se buscaba institucionalizar su tarea a través de la Academia Argentina de la Lengua como guardianes de la pureza del castellano. En contraposición, en estas líneas se define la misión del escritor como la defensa del decoro humano por sobre divisiones lingüístico-culturales, religiosas y políticas, retomando así una tradición de raigambre humanista.

Lo interesante es que Gerchunoff reelabora esta tradición, por una parte, a través de una metáfora que refuerza la concepción cuasi divina de la misión del escritor a la vez que realiza en sí misma aquello postulado como la prioridad de la hora histórica: la conciliación de diferencias culturales, étnicas y religiosas ante la homogenización de los nacionalismos. Y, por otra parte, que él mismo encarna la figura del escritor humanista, pero exaltando su pertenencia judeoargentina. La "llama creativa del Espíritu Santo", generadora de comunidades fraternales, resplandece en la propia figura del autor-prologuista en la conjunción entre lo argentino y lo judío, conjugados ahora -a diferencia de su imagen de 1910- en un mismo presente, pues no solo afirma explícitamente su judeidad (Gerchunoff, 1960: 49), sino que elige como epígrafe de la carta nada menos que el siguiente pasaje del Martín Fierro: "De naides sigo el ejemplo / Naide a dirigirme viene"... (Gerchunoff, 1960: 12). De esta manera, en un mismo gesto Gerchunoff elige irónicamente la vitalidad del lenguaje de la gauchesca frente a la esterilidad de las academias (Szurmuk, 2018: 304) e inscribe la "advertencia" de este prefacio en la veta contestataria del "poema nacional"... y no ya en el pacto estatal de su final. ${ }^{8}$

Ahora bien, el rechazo del espíritu académico, sustento de la defensa de identidades comunitarias e intelectuales no homogeneizadas, informa la misma estructura de este prólogo. Contra el horizonte de expectativas de los lectores imaginarios (la autoridad y los estudiantes de Caracatambo), este texto prefacial tiene una dimensión desproporcionada con relación al texto prologado. Además, la misma ambigüedad en cuanto a su estatuto de realidad desestabiliza todo intento de definición esquemática. Así, por ejemplo, su función autoral o actoral (Genette, 2001) sería indecidible tanto porque la irrealidad del destinatario contagia al enunciador -poniendo en crisis la definición del comienzo de la novela- como debido a que la narración central se encuentra a cargo de un personaje que escribe la biografía de "El hombre importante". El autor no restringe su escritura a ningún molde genérico, ni para el prefacio ni para la narración, pues encasillar de esa forma la escritura sería solo una preocupación estéril de académicos. No casualmente la respuesta a la segunda pregunta de Olavide se desplaza a un breve espacio final, y ello para manifestar su improcedencia:

\begin{abstract}
¿Novela, historia, fábula? "Los estudiantes de Caracatambo quieren saberlo" -apunta usted en ElOrinoco-. Lo que les aconsejo es que lean El hombre importante. Con ello tendrán alegría y provecho. Avíseles, eso sí, que utilizaré esta epístola doctrinal como prólogo de la edición de Montevideo. ¿Cómo -interrogará el público- un prólogo tan excesivo y heterogéneo para un libro tan breve y tan cohesivo? Sí, Maestro de Ollantacaibo. Bernard Shaw [...] puso en auge los prefacios desmesurados. [...]. Le niego a Bernard Shaw la prerrogativa de ser más judío que yo, cuando, en realidad, yo soy más Bernard Shaw que él. (Gerchunoff, 1960: 49, subrayado propio)
\end{abstract}

En definitiva lo que Gerchunoff estaba advirtiendo a través de este prólogo era que el avance del autoritarismo y del control estatal, con la consecuente restricción de la inmigración y la tendencia a la exclusión de la diversidad étnica y cultural, no era un lejano problema de ultramar ni tampoco una cuestión circunscripta a la política, sino 
que todos los ámbitos de la cultura y la sociedad se estaban viendo afectados. Ante ese panorama, exaltar la libertad creativa desestructurando el horizonte de expectativa sobre el prólogo y la "pureza" genérica de la obra era una toma de posición político-cultural.

Ahora bien, la "edición de Montevideo" mencionada en el fragmento citado es, en verdad, la primera que tuvo este libro, con lo cual se juega con la idea de una versión anterior de El hombre importante que habría circulado sin prologar, o al menos sin este prólogo. Este juego de versiones hipotéticas podría vincularse con el hecho de que Gerchunoff escribió al parecer el texto central en 1929 (Kantor, 1960: 15), mientras que la "Advertencia pertinente" está fechada en 1934. De modo tal que el autor originalmente no habría pensado en ella, sino que sería hija de la nueva coyuntura histórico-cultural.

En este sentido, no es menor el juicio del prologuista en cuanto a que desde la caída de Julio A. Roca no hubo líderes genuinos en la Argentina, así como su advertencia de que el país necesita verdaderos nuevos guías (Gerchunoff, 1960: 41). En otras palabras, el prólogo dejaría en claro en el conjunto de la obra que la sátira política a Yrigoyen en el texto prologado no se correspondía con un apoyo de su autor al general Uriburu, ya que en razón de su deber de escritor antiacadémico se defiende ante todo "el decoro humano". En esa nueva coyuntura parecía urgir la sutil prevención de que tanto el caudillo militar como el caudillo democrático continuaban el linaje de falsos líderes de la patria: ni con el populismo de Yrigoyen ni con el autoritarismo de Uriburu, parecía advertir Gerchunoff, podía construirse una comunidad nacional integrada... una Nación opuesta a la comunidad de Orígenes.

\section{Breve reflexión final}

Para culminar este trabajo, es preciso subrayar la reflexión sobre el prólogo que se encuentra en la "Advertencia pertinente". Allí se pone de manifiesto la flexibilidad, la inestabilidad productiva de sus rasgos y su capacidad de incorporar en sí otras formas genéricas. Así, son diversos los modos de autodenominación de este texto: "advertencia", "carta", "historia", "ensayo", "epístola doctrinal", para no reiterar la ambigüedad de su estatuto de ficción o realidad. El prólogo se vuelve de esta manera un género secundario como la novela, a tal punto que puede llegar a ser él mismo una novela.

Forma cambiante, también su función lo es. Sin embargo, a partir del análisis aquí desarrollado, pueden vislumbrarse dos invariantes funcionales en las instancias prologales de las obras de Gerchunoff: el prólogo como instancia de construcción de imagen de autor y espacio para dirimir posicionamientos ideológicos del prologuista (y/o el autor), en este caso sobre los procesos de integración. En este sentido, sendos prólogos de Los gauchos judios y de El hombre importante permitieron comprender sus vínculos - de diálogo y/o tensión- con sus contextos de producción sociopolíticos, pero también más específicamente con las corrientes y polémicas del campo literariointelectual. De esta manera, por un lado, el texto de Leguizamón clarificó la relación del autor con el nacionalismo del Centenario y su ideología del crisol de razas y, por otro lado, el prólogo ficcional de El hombre importante iluminó la posición del autor y su obra respecto al avance del nacionalismo conservador de la década de 1930 y su convicción de una imperiosa defensa del pluralismo cultural en la Argentina.

Sin embargo, no sería adecuado concluir de las diferencias entre prólogos y obras prologadas de 1910 y 1936 respectivamente la existencia de una transformación radical y lineal de Gerchunoff ni en cuanto a su concepción sobre los procesos de integración de los judíos a la Argentina y su factibilidad, ni en cuanto a su posicionamiento en 
el campo literario-intelectual local. Y ello no solo por los núcleos constantes en su ideario, tales como liberalismo, democratismo, civismo argentino y homologación entre tradición judía y cristiana, sino también porque la reedición en 1936 de Los gauchos judios parecería indicar de modo más claro que nunca la persistencia de las tensiones presentes en él: entre la particularidad étnica de la comunidad de origen y la cultura mayoritaria argentina, ente el hispanismo y el rechazo a las academias, entre el telurismo homogeneizador del "ser argentino" y la exaltación de lo pluricultural.

En efecto, dos años después del alegato contra la Academia de Caracatambo y la crítica demoledora contra el espíritu académico, reaparece su obra prima en una versión "corregida y aumentada" donde, sorprendentemente, la homogeneización lingüístico-castiza del texto se ha profundizado y la instancia prologal de Leguizamón vuelve a guiar su lectura. No parece tratarse entonces de una mera reimpresión, sino antes bien de una planificada intervención literario-política. No cabe duda de que ante la profundización del nacionalismo católico, las restricciones a la inmigración y la virulencia local y mundial del discurso judeofóbico, la imagen idílica de judíos agricultores -y de un escritor judeoargentino- engrandeciendo la Nación podía ser nuevamente otra forma, menos revulsiva pero necesaria, de luchar por su integración. 


\section{Dibliografía}

" Aizenberg, E. (2002). Books and Bombs in Buenos Aires: Borges, Gerchunoff and Argentine-Jewish Writing. Hanover: University Press of New England

" Altamirano, C. y Sarlo, B. (1983). Ensayos argentinos: De Sarmiento a la vanguardia. Buenos Aires: Centro Editor de América Latina.

» Avni, H. (1983). Argentina y la historia de la inmigración judía 1810-1950. Buenos Aires: Magnes.

»Blanco, M. (1995, julio-agosto). La Academia Argentina de Letras y el español de la Argentina. Cuadernos Americanos. Nueva época, IX, nº 52, pp. 254-269.

"Chein, D. J. (2012). Nación y provincia: génesis del discurso de la identidad entrerriana en la literatura nativista argentina (1895-1915). A Contracorriente: Una revista de historia social y literatura de América Latina, vol. 9, no 2. Recuperado de $<$ http://acontracorriente.chass.ncsu.edu/index.php/acontracorriente/article/ view/171> (consulta: 10-05-2017).

»De Giovanni, F. (2000, abril-junio). Inmigración, nacionalismo cultural, campo intelectual: El proyecto creador de Alberto Gerchunoff. Revista Iberoamericana, no 191 , pp. 367-381.

" Di Miro, M. (2017). “Gaúchos y gauchos judíos: João Simões Lopes Neto/Alberto Gerchunoff”. En Croce, M. (Comp.), Historia comparada de las literaturas argentina y brasileña, vol. 3 (pp. 87-108). Córdoba: Eduvim.

» Feierstein, R. (2013). Alberto Gerchunoff: el argentino más judío, el judio más argentino. Buenos Aires: Capital Intelectual.

»Freidenberg, J. (2013). La invención del gaucho judio: Villa Clara y la construcción de la identidad argentina. Buenos Aires: Prometeo.

» Genette, G. (2001). Umbrales. Traducción de Susana Lage. México: Siglo Veintiuno.

"Gerchunoff, A. (1910). Los gauchos judíos. Buenos Aires: Joaquín Sesé.

" Gerchunoff, A. (1918). El nuevo régimen. Buenos Aires: Otero y García.

" Gerchunoff, A. (1919) Cuentos de ayer. Buenos Aires: Ediciones Selectas América.

" Gerchunoff, A. (1924) El cristianismo precristiano. Buenos Aires: Asociación Hebraica.

»Gerchunoff, A. (1925) “El hombre de las manos luminosas”. En La asamblea de la bohardilla. Buenos Aires: Gleizer.

» Gerchunoff, A. (1960). El hombre importante. Buenos Aires: Hachette.

» Gerchunoff, A. (2015). “Autobiografía”. En Senkman, L. (Ed.), Entre Ríos, mi país. Paraná: Eduner.

" Glozman, M. (2013). Corporativismo, política intelectual y regulación lingüística: la creación de la Academia Argentina de Letras. Lenguaje, no 41 (2), pp. 455-478.

» Gramuglio, M. T. (1993). Leopoldo Lugones. La construcción de imágenes de escritor. Hispamérica, no 64/65, Latin American Studies Center, University of Maryland, pp. 5-22.

" Gramuglio, M. T (2013). Nacionalismo y cosmopolitismo en la Literatura Argentina. Rosario: Editorial Municipal de Rosario. 
» Halperin Donghi, T. (2013). La Argentina y la tormenta del mundo. Ideas e ideologías entre 1930 y 1945. Buenos Aires: Siglo XXI.

» Jaroslavsky de Lowy, S. (1957). Alberto Gerchunoff: vida y obra. Revista Hispánica Moderna, nㅇ- 3-4, pp. $205-257$.

»Kantor, M. (1960). Sobre la obra y el anecdotario de Alberto Gerchunoff. Buenos Aires: Hachette.

»Laura, R. (1956). Lisandro de la Torre, el solitario de Pinas. Buenos Aires: Hemisferio.

»Leguizamón, M. (1910). “Prólogo”. En Gerchunoff, Alberto, Los gauchos judíos. Buenos Aires: Joaquín Sesé.

"Lewis, A. (2007), “Shofar”. En Skolnik, Fred (Ed.), Encyclopaedia Judaica (Second Edition), vol. 18 (pp. 506-508). Nueva York: Macmillan.

"Lindstrom, N. (1989). Jewish issues in Argentine literature: from Gerchunoff to Szichman. Columbia: University of Missouri Press.

»Ludmer, J. (1988). “El libro del pacto”. En El género gauchesco. Un tratado sobre la patria. Buenos Aires: Sudamericana.

»Lugones, L. (1916). El payador. Tomo primero. Hijo de la pampa. Buenos Aires: Otero \& Co-Impresores.

"Lvovich, D. (2003). Nacionalismo y antisemitismo en la Argentina. Buenos Aires: Vergara.

»Marquis Stambler, B. (1985). Vida y obra de Alberto Gerchunoff. Madrid: Albar.

» Mirelman, V. (1988). En busca de una identidad. Los inmigrantes judíos en Buenos Aires, 1890-1930. Buenos Aires: Milá.

»Peris Llorca, J. (2014, diciembre). Los gauchos judíos, de Alberto Gerchunoff: el gaucho como herencia simbólica nacionalizadora en la Argentina del Centenario. Artifara, no 14, Turín. Recuperado de <http://www.ojs.unito.it/index.php/ artifara> (Consulta: 15-02-2017).

»Presentó su renuncia uno de los miembros (1931, 21 de agosto). Diario La Nación, Buenos Aires.

» Senkman, L. (1983). La identidad judía en la Literatura Argentina. Buenos Aires: Pardés.

»Sosnowski, S. (1978). Contemporary Jewish-Argentine Writers: Tradition and Politics. Latin American Literary Review, no 12, pp. 1-4.

»Szurmuk, M. (2018). La vocación desmesurada: una biografía de Alberto Gerchunoff. Buenos Aires: Sudamericana.

»Tato, M. I. (2006, abril). Los ángeles redentores: el radicalismo bajo la lente crítica de Alberto Gerchunoff. Hyspamerica, año XXXV, no 103, pp. 33-50.

»Tato, M. I. (2007, enero-junio). Del crisol de razas a la Argentina desintegrada: un itinerario de la idea de nación (1922-1932). Historia y Política, nº 17, Madrid, pp. $153-173$.

"Viñas, D. (1964). Literatura argentina y realidad política. Buenos Aires: Centro Editor de América Latina.

»Zanatta, L. (1996). Del estado liberal a la nación católica. Iglesia y Ejército en los orígenes el peronismo, 1930-1943. Buenos Aires: Universidad Nacional de Quilmes. 